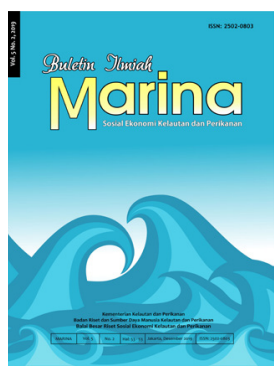

BULETIN ILMIAH MARINA

SOSIAL EKONOMI KELAUTAN DAN PERIKANAN

http://ejournal-balitbang.kkp.go.id/index.php/mra

p-ISSN: 2502-0803

e-ISSN: 2541-2930

Nomor Akreditasi: 10/E/KPT/2019

\title{
KESENJANGAN GENDER PADA PEMANFAATAN PERIKANAN SKALA KECIL DI KABUPATEN NATUNA
}

\section{Gender Gap of Small Scale Fisheries Utilization in Natuna Regency}

\author{
*Armen Zulham, Rani Hafsaridewi, Hikmah, \\ Permana Ari Soejarwo, dan Bayu Vita Indah Yanti \\ Balai Besar Riset Sosial Ekonomi Kelautan dan Perikanan \\ Gedung BRSDM KP I Lt. 4 \\ Jalan Pasir Putih Nomor 1 Ancol Timur, Jakarta Utara, Indonesia \\ Telp: (021) 64711583 Fax: 64700924
}

Diterima tanggal: 30 April 2020 Diterima setelah perbaikan: 17 Desember 2020

Disetujui terbit: 21 Desember 2020

\begin{abstract}
ABSTRAK
Kesenjangan gender atau perbedaan peran laki-laki dan perempuan terhadap akses dan kontrol dalam pengambilan keputusan pada aktivitas perikanan skala kecil di Kabupaten Natuna masih tinggi. Penelitian ini bertujuan untuk menganalisis kesenjangan gender pada pemanfaatan perikanan skala kecil di Kabupaten Natuna; dan merumuskan strategi untuk mencapai kesetaraan gender. Data yang digunakan adalah data primer yang terpilah gender. Data primer dikumpulkan pada bulan Agustus 2019 terhadap 52 responden nelayan penangkap ikan skala kecil di 5 (lima) kecamatan di Pulau Bunguran Kabupaten Natuna. Data diolah dan dianalisis dengan menggunakan software excel untuk memperoleh persentase tiga keputusan responden pada 5 kecamatan tersebut. Hasil analisis menunjukkan pengambilan keputusan pada perikanan skala kecil di Kabupaten Natuna masih didominasi oleh laki-laki. Kesenjangan gender terjadi pada aktivitas persiapan penangkapan ikan, kegiatan penangkapan ikan di laut, paska panen (penangkapan) ikan. Oleh karena itu, Pemerintah Daerah Kabupaten Natuna perlu merancang program stimulasi ekonomi untuk membuka lapangan kerja bagi perempuan dan memberi peluang partisipasi terhadap istri nelayan dalam pengambilan keputusan, dengan melibatkannya dalam kegiatan pelelangan ikan di tempat pelelangan ikan (TPI) atau pengurus armada penangkapan ikan.
\end{abstract}

Kata Kunci: kesenjangan gender; perikanan tangkap skala kecil; kesetaraan gender, Natuna

\begin{abstract}
The gender gap or the different role of access and control among men and women on the decision making process in small scale fishery activities in Natuna is remain high. The purpose of this research is to analyze the gender gap in small-scale fisheries utilization and to provide the strategy to achieve gender equality. Gender disaggregated primary data were collected in August 2019 from 52 respondents of the small scale fishermen in 5 sub regency in the Bungguran Island of Natuna Regency. The data were processed using excel software to find out the percentage of 3 reasons for respondent participation. The findings shows that decision maker is dominated by fishermen. The gender gap occurred in preparation process of the fishing activities, fishing activities, and post fishing activities. Therefore, government of Natuna Regency must prepare the economic stimulus program for providing labor opportunities for women, encourage the participation of the fishermen's wife in decision making process by involving them in fish auction activity or as manager of fishing fleets.
\end{abstract}

Keywords: gender gap; small scale fisheries; gender equality; Natuna 


\section{PENDAHULUAN}

\section{Latar Belakang}

Gender merupakan konsep sosial, relasi laki-laki dan perempuan mengenai perannya di dalam masyarakat, komunitas, dan keluarga (Barclay, et al., 2019; Ponthieux \& Dominique, 2015). Gender menjadi isu pembangunan perikanan karena ada perbedaan kekuatan akses, kontrol serta partisipasi laki-laki dan perempuan dalam pengambilan keputusan (Bennett, 2005; Lopes, Duarte, \& Tilley, 2020). Kasus ketidaksetaraan gender sudah pernah terjadi di Jawa saat program revolusi hijau (Sofiani, 2009; Dunham, 2008), serta program tambak inti rakyat di Pantura Jawa dilaksanakan (Zulham, 2020). Winarno (2003) \& Dunham (2008) menyimpulkan bahwa perempuan di Jawa tidak memperoleh akses dan kontrol serta manfaat dari dua program itu. Lebih lanjut, Dunham (2008) meyebutkan bahwa program tersebut justru menimbulkan kesenjangan sosial di dalam masyarakat. Perempuan tidak memperoleh akses dan kontrol terhadap keputusan alokasi penggunaan sumber daya pada program tersebut, sehingga mereka tersisih dari pekerjaan yang biasa dilakukan (Rahayu, 2016).

Menurut konsep Women in Development yang digagas oleh Moser (1993), perempuan diikutsertakan dalam program agar mendapat equitas, sehingga memperoleh kesejahteraan. Namun, faktanya perempuan sulit mendapat equitas, karena akses dan kontrol tidak diperoleh, seperti pada program revolusi hijau dan tambak inti rakyat yang telah disebutkan di atas. Pada sisi lain konsep Gender and Development (Levy, 1996) dikembangkan untuk mendorong kesetaraan laki-laki dan perempuan melalui akses, kontrol, partisipasi dan manfaat dalam keputusan alokasi berbagai potensi sumber daya dari program pembangunan.

Pemerintah Indonesia berupaya menghilangkan kesenjangan tersebut melalui pengorganisasian perempuan dalam kelompokkelompok usaha, sehingga mereka mendapat akses dan kontrol terhadap berbagai kegiatan pembangunan (Moser, 1993; Hakiki, et al., 2019). Pada masyarakat perikanan, pengorganisasian perempuan dilakukan melalui kelompok-kelompok usaha, seperti Kelompok Pengolah dan Pemasar (Poklahsar) dan Kelompok Usaha Bersama (KUB), Kelompok Pembudidaya Ikan (Pokdakan) (Kurniawan, Triyanti, \& Nurlaili, 2020; Shafitri,
Triyanti, \& Zulham, 2020). Dinas Kelautan dan Perikanan Kabupaten Natuna (2020) mencatat pada tahun 2019, jumlah Poklahsar, KUB, dan Pokdakan masing-masing 82 kelompok, 172 kelompok, dan 132 kelompok. Pengorganisasian perempuan dalam kelompok tersebut merupakan strategi agar perempuan berpartisipasi di dalam perekonomian, sehingga mereka dapat memperbaiki ekonomi rumah tangga (Triyanti, Shafitri, \& Kurniawan, 2020). Di Cituis Kabupaten Tangerang mendorong perempuan bekerja pada berbagai kegiatan produktif (Hikmah, Nurlaili, \& Soejarwo, 2020). Hikmah et al. (2020) melaporkan juga perempuan di Cituis mendapat akses meminjam uang di koperasi untuk membiayai kegiatan penangkapan ikan yang dilakukan suami.

Ketidaksetaraan gender terkait dengan akses serta kontrol laki-laki dan perempuan pada masyarakat perikanan di Kabupaten Natuna perlu diidentifikasi paska implementasi Sentra Kelautan dan Perikanan Terpadu (SKPT) Selat Lampa yang dibangun untuk mengembangkan perekonomian dan perikanan skala kecil di Kabupaten Natuna dan memberikan kesempatan kerja dan meningkatkan pendapatan masyarakat perikanan tersebut (Wardono, Muhartono, Apriliany, Hikmah \& Zulham, 2020; Zulham, Subaryono, \& Regy, 2017). Pada masyarakat perikanan Natuna, perempuan dipersepsikan mengerjakan urusan domestik dan laki-laki melaksanakan pekerjaan produktif mencari uang (termasuk menangkap ikan di laut). Norma sosial seperti itu telah menyebabkan perempuan hanya mengerjakan urusan rumah tangga saja (domestik) dan sulit memperoleh akses dan kontrol terhadap kegiatan produktif dalam perekonomian atau menjadi sub-ordinat laki-laki pada berbagai aktivitas perekonomian (Rahayu, 2016; World Economic Forum, 2014). Pada pengurusan membongkar ikan \& perdagangan ikan di tempat pendaratan ikan akses perempuan terhadap kegiatan tersebut adalah nihil, karena keputusan pada lokasi pendaratan ikan didominasi oleh laki-laki. Akibatnya, berbagai kegiatan perekonomian yang potensial berkembang di tempat pendaratan ikan, seperti usaha pengolahan ikan atau pedagang eceran tidak terwujud.

Oleh sebab itu, penelitian ini fokus pada 2 (dua) tujuan utama, yaitu 1) menganalisis kesenjangan gender pada aktivitas perikanan skala kecil di Kabupaten Natuna; 2) merumuskan strategi untuk mencapai kesetaraan gender pada masyarakat perikanan skala kecil di Kabupaten Natuna. 


\section{Pendekatan IImiah}

Penelitian dilakukan pada bulan Agustus 2019 di 5 (lima) kecamatan di Kabupaten Natuna, yaitu; Bunguran Selatan, Bunguran Timur, Bunguran Timur Laut, Bunguran Utara, dan Pulau Tiga. Data yang dikumpulkan adalah data primer terpilah gender yang dikumpulkan dari 52 responden yang dipilih secara acak untuk mendapat informasi tentang akses dan kontrol, serta partisipasi laki-laki dan perempuan terhadap berbagai aktivitas pada perikanan skala kecil. Data yang dikumpulkan diolah dengan statistik sederhana yang hasilnya dijelaskan secara deskriptif sesuai dengan fenomena lapangan. Analisis akses dan kontrol peran laki-laki dan perempuan dalam pengambilan keputusan pada berbagai aktivitas ekonomi di dalam pemanfaatan perikanan skala kecil digunakan untuk mempelajari peran perempuan di dalam masyarakat perikanan di Kabupaten Natuna. Analisis prescriptive (Lepeniotia, Bousdekisa, Apostoloua, \& Mentzas, 2020) digunakan untuk menyusun strategi kesetaraan gender pada perikanan skala kecil berdasarkan data dan informasi yang diperoleh. Analisis yang terakhir ini memanfaatkan semua informasi dan data lapangan untuk menyusun langkah langkah strategis untuk mendorong peningkatan partisipasi perempuan (istri nelayan) berkontribusi pada perekonomian Kabupaten Natuna.

\section{KESENJANGAN GENDER PADA AKTIVITAS PERIKANAN SKALA KECIL}

Perempuan pada aktivitas perikanan skala kecil merupakan bagian dari angkatan kerja di Kabupaten Natuna. Data terpilah gender dari BPS Kabupaten Natuna tentang jumlah perempuan dan laki-laki yang bekerja pada kegiatan perikanan belum tersedia. Terkait dengan hal itu, perempuan di Kabupaten Natuna tidak menangkap ikan ke laut, tetapi perempuan bisa ikut serta di dalam keputusan-keputusan untuk menangkap ikan ke laut, karena keputusan itu berpengaruh terhadap ekonomi rumah tangga nelayan. Oleh sebab itu, pengamatan lapangan tentang peran perempuan di dalam pengambilan keputusan dijadikan acuan menjelaskan fenomena gender pada perikanan skala kecil. Partisipasi perempuan terhadap keputusan pemanfaatan perikanan skala kecil, termasuk di Kabupaten Natuna dipengaruhi oleh norma dan budaya, stereotype pekerjaan terhadap perempuan, politik program bantuan (Groenmeyer, 2015; Harper, 2016; Paul \& Meena, 2016; Rahmawati \& Abdulkadir-Sunito, 2013), serta kebijakan pembangunan ekonomi di Kabupaten Natuna. Hakikat pembangunan ekonomi tersebut adalah memberi peluang yang sama antara perempuan dan laki-laki dan tidak ada diskriminasi (ILO, 2016).

Beberapa kegiatan pemanfaatan perikanan skala kecil pada persiapan penangkapan ikan, penangkapan ikan dan paska penangkapan ikan disebut tidak adil gender, karena keputusannya tidak dapat diakses dan dikontrol oleh perempuan. Ketidakadilan gender (gender inequality) tersebut menurut (Anonim, 2015) lebih banyak dipengaruhi oleh norma sosial. Kesenjangan gender yang dibahas pada penelitian ini meliputi akses (kesempatan/peluang) dan kontrol (wewenang/kekuasaan) perempuan di dalam proses pengambilan keputusan (Villamor, Meine, Utkur, Ma Elena, \& Delia, 2014) pada kegiatan persiapan penangkapan ikan, penangkapan ikan, dan paska penangkapan ikan. Akses adalah kesempatan (opportunity) memanfaatkan program pembangunan atau sumber daya. Kontrol adalah wewenang untuk menentukan pemanfaat program pembangunan atau sumber daya dan siapa yang menggunakannya. Partisipasi adalah keterwakilan laki-laki dan perempuan di dalam berbagai program atau sumber daya. Pada kekerabatan patrilineal di Natuna, perempuan biasanya mendapat akses untuk berpartisipasi, namun tidak mendapat kontrol. Kontrol tersebut merupakan salah satu faktor penyebab terjadinya kesenjangan gender di Natuna.

1. Kesenjangan gender pada persiapan penangkapan ikan

Proses pengambilan keputusan pada persiapan penangkapan ikan, meliputi keputusan tentang penentuan lokasi penangkapan ikan, penentuan alat tangkap yang digunakan untuk menangkap ikan, keputusan mengganti dan membeli alat tangkap baru, serta keputusan tentang pengelolaan investasi. Empat kegiatan tersebut merupakan kegiatan yang keputusannya dapat ditentukan perempuan bersama laki-laki, karena terkait erat dengan sumber ekonomi rumah tangga (Fitriana \& Kurufat, 2020). Tabel 1 menunjukkan fenomena akses dan kontrol perempuan tentang pengambilan keputusan penentuan lokasi penangkapan ikan, menentukan alat tangkap ikan, membeli alat tangkap ikan baru, serta mengelola investasi penangkapan ikan.

Pada Kecamatan Bunguran Selatan, Bunguran Timur, dan Kecamatan Bunguran Timur 
Laut, akses dan kontrol perempuan terhadap keputusan penentuan lokasi penangkapan ikan dapat dikatakan tidak ada, meskipun perempuan mengetahui pada komunitas perikanan terjadi "jual beli" koordinat lokasi penangkapan ikan. Fenomena penjualan jual beli koordinat ini tidak pernah terjadi di perairan lain di Indonesia. Keputusan penentuan lokasi penangkapan ikan $100 \%$ didominasi oleh laki-laki. Keputusan terjadi pada siang hari ketika nelayan berkumpul pada warung kopi di tempat pendaratan ikan. Keputusan itu diambil pada tempat yang tidak pernah ada perempuan.

Tabel 1 menunjukkan bahwa pada Kecamatan Pulau Tiga, 66,7\% keputusan penentuan lokasi penangkapan ikan didominasi oleh laki-laki. Keputusan ini terjadi saat berkumpul nelayan mendiskusi perkembangan lokasi penangkapan ikan di tempat pendaratan ikan, sementara perempuan tidak ada pada tempat tersebut. Sebanyak 33,3\% keputusan penentuan lokasi penangkapan ikan adalah kompromi antara laki-laki dan perempuan dan terjadi di rumah responden. Sementara di Bunguran Utara, keputusan 100\% diambil atas dasar kesepakatan laki-laki dan perempuan di tempat tinggal mereka sebelum melaut. Keputusan kompromi tersebut bisa terjadi karena biaya untuk "pembelian koordinat" lokasi penangkapan ikan akan menggunakan biaya rumah tangga.

Akses dan kontrol terhadap keputusan penentuan jenis alat tangkap didominasi oleh laki-laki. Dominasi keputusan laki-laki sangat dominan di Kecamatan Bunguran Selatan, Bunguran Timur, Bunguran Timur Laut, dan Bunguran Utara. Pada Kecamatan Bunguran
Timur Laut, dan Pulau Tiga, akses perempuan terhadap keputusan tersebut dapat dilakukan melalui kompromi dengan laki-laki, masing-masing $20 \%$ dan $33,3 \%$ (Tabel 1). Peluang perempuan di dalam mengambil keputusan penentuan jenis alat tangkap ikan dapat dikatakan tidak terjadi. Demikian juga dengan kontrol (kewenangan) perempuan terhadap keputusan penentuan alat tangkap tersebut. Kesetaraan gender di Kabupaten Natuna yang memberi peluang dan kewenangan penentuan alat tangkap kepada perempuan dapat dikatakan belum terwujud. Pada pemilihan jenis alat tangkap tersebut keputusannya tidak mempengaruhi keuangan rumah tangga. Alat tangkap tersebut diperoleh dari "toke" dengan sejumlah persyaratan yang ditetapkan "toke".

Pada pembelian alat tangkap ikan baru, akses dan kontrol perempuan terhadap pembelian alat tangkap baru di Kecamatan Bunguran Utara, Kecamatan Bunguran Timur, Bunguran Timur Laut, dan Kecamatan Pulau Tiga diperoleh melalui kompromi laki-laki dan perempuan. Keputusan kompromi laki-laki dan perempuan yang paling tinggi terdapat di Bunguran Utara (100\%), sementara di Kecamatan Bunguran Timur $(10,5 \%)$, Bunguran Timur Laut $(5,3 \%)$, dan Pulau Tiga $(33,3 \%)$. Kompromi pengambilan keputusan itu dilakukan karena pembelian alat tangkap baru itu memerlukan uang, yang dapat mempengaruhi keuangan rumah tangga.

Kompromi dalam pengelolaan investasi penangkapan ikan ditemukan di Bunguran Utara (100\%), Bunguran Selatan (87,5\%), dan Bunguran Timur Laut $(60 \%)$ (Tabel 1). Keputusan tersebut

Tabel 1.Kesenjangan Gender pada Pengambilan Keputusan Persiapan Penangkapan Ikan di Natuna, 2019.

\begin{tabular}{|c|c|c|c|c|c|c|c|c|c|c|c|c|c|}
\hline \multirow[t]{2}{*}{ Kecamatan } & \multirow[t]{2}{*}{$\mathbf{N}$} & \multicolumn{3}{|c|}{$\begin{array}{l}\text { Lokasi Penangkapan Ikan } \\
\text { (\%) }\end{array}$} & \multicolumn{3}{|c|}{$\begin{array}{l}\text { Menentukan Alat } \\
\text { Tangkap Ikan (\%) }\end{array}$} & \multicolumn{3}{|c|}{$\begin{array}{l}\text { Membeli Alat } \\
\text { Tangkap Ikan } \\
\text { Baru (\%) }\end{array}$} & \multicolumn{3}{|c|}{$\begin{array}{l}\text { Mengelola Investasi } \\
\text { Penangkaan Ikan (\%) }\end{array}$} \\
\hline & & (a) & (b) & (c) & (a) & (b) & (c) & (a) & (b) & (c) & (a) & (b) & (c) \\
\hline $\begin{array}{l}\text { Bunguran } \\
\text { Selatan }\end{array}$ & 8 & 100,0 & 0,0 & 0,0 & 100,0 & 0,0 & 0,0 & 100 & 0 & 0 & 12,5 & 0,0 & 87,5 \\
\hline Bunguran Timur & 19 & 100,0 & 0,0 & 0,0 & 100,0 & 0,0 & 0,0 & 89,5 & 0 & 10,5 & 68,4 & 0,0 & 31,6 \\
\hline $\begin{array}{l}\text { Bunguran Timur } \\
\text { Laut }\end{array}$ & 15 & 100,0 & 0,0 & 0,0 & 80,0 & 0,0 & 20,0 & 94,7 & 0 & 5,3 & 40,0 & 0,0 & 60,0 \\
\hline Bunguran Utara & 5 & 0,0 & 0,0 & 100,0 & 100,0 & 0,0 & 0,0 & 0 & 0 & 100 & 0,0 & 0,0 & 100,0 \\
\hline Pulau Tiga & 5 & 66,7 & 0,0 & 33,3 & 66,7 & 0,0 & 33,3 & 66,7 & 0 & 33,3 & 66,7 & 0,0 & 33,3 \\
\hline
\end{tabular}

Keterangan: $\mathrm{N}$ = jumlah responden; (a) dominasi laki-laki; (b) dominasi perempuan; (c) dominasi laki-laki dan perempuan. Sumber: Data Primer Diolah, 2019

${ }^{1}$ Toke adalah pedagang ikan antar pulau yang memberi modal atau biaya kepada nelayan Kabupaten Natuna untuk menangkap ikan dan menjadi supplier ikan untuk eksportir di Tanjung Balai Karimun dan Batam. 
menurut Damsar \& Indrayani (2009) disebut keputusan keterlekatan gender yang solid (strong gender equality). Sementara kesetaraan gender dalam pengelolaan investasi di Bunguran Timur $(31,6 \%)$, dan Pulau Tiga $(33,3)$ disebut sebagai kesetaraan gender yang rapuh (fragile gender equality).

2. Kesenjangan gender pada kegiatan penangkapan ikan

Pada kegiatan penangkapan ikan, perempuan tidak melakukan kegiatan penangkapan ikan secara langsung di laut karena norma yang berlaku dipersepsikan demikian. Dominasi laki-laki di dalam mengambil keputusan lama melaut dan jumlah tenaga kerja saat melaut terlihat dari jawaban responden di Kecamatan Bunguran Selatan dan Kecamatan Bunguran Timur (Tabel 2). Penelitian yang dilakukan oleh Zulham et al. (2017) \& Zulham, (2020) menunjukkan bahwa di Kabupaten Natuna, keputusan nelayan lama melaut itu ditentukan ketika nelayan berkumpul di tempat pendaratan ikan bersama pedagang ikan setempat (toke), penentuan ini terkait dengan perbekalan melaut yang harus disediakan toke. Selain itu, dalam melakukan penangkapan ikan di laut, nelayan perikanan skala kecil Kabupaten Natuna dilakukan bersama kerabat dekat.

Keputusan menentukan lama melaut dan jumlah tenaga kerja yang melaut di Kecamatan Bunguran Selatan dan Bunguran Timur menunjukkan kuatnya dominasi laki-laki. Akses (kesempatan) dan kontrol (kewenangan) perempuan terhadap hal itu dapat dikatakan tidak ada. Hal ini menunjukkan pengaruh toke sangat kuat dan mempengaruhi relasi gender pada dua kecamatan itu. Toke telah berinvestasi membiayai kegiatan penangkapan ikan, sehingga keinginan toke harus diikuti.
Namun, akses dan kontrol perempuan terhadap keputusan lama melaut dan jumlah tenaga kerja saat melaut pada responden di Kecamatan Bunguran Timur Laut, Bunguran Utara, dan Kecamatan Pulau Tiga menunjukkan perempuan di Kecamatan tersebut mendapat peluang dan wewenang yang sama, artinya dominasi toke mulai berkurang pada tiga kecamatan tersebut. Keputusan kompromi tentang lama melaut di Bunguran Utara, Bunguran Timur Laut, dan Pulau Tiga masing-masing adalah $100 \%, 46,7 \%$, dan $66,7 \%$. Sementara tentang penggunaan tenaga kerja untuk melaut di Bunguran Utara 100\%, Bunguran Timur Laut 53,3\%, dan Pulau Tiga $33,3 \%$. Masyarakat di kecamatan tersebut telah berinteraksi dengan masyarakat pendatang dalam aktivitas penangkapan ikan. Hal ini terjadi sejak adanya program bantuan dan program SKPT yang mendorong nelayan setempat bekerja sama dengan nelayan pendatang terkait dengan transfer teknologi serta ketrampilan melaut. Interaksi ini berpengaruh terhadap keputusan kompromi laki-laki dan perempuan karena terkait dengan pendapatan rumah tangga.

Keputusan kompromi terjadi dipengaruhi adanya interaksi dengan pedagang ikan dari Batam serta dari Tanjung Balai Karimun. Interaksi tersebut juga berpengaruh terhadap relasi gender tentang lama menangkap ikan dan penentuan pekerja yang melaut yang menentukan perolehan pendapatan rumah tangga nelayan.

\section{Kesenjangan gender paska panen (penangkapan) ikan}

Relasi gender pada kegiatan paska panen ikan terkait dengan penentuan lokasi mendaratkan ikan, alokasi penjualan hasil tangkapan, dan sistem penjualan hasil tangkapan. Perempuan, walaupun tidak melaut namun partisipasinya mempengaruhi kegiatan tersebut. Akses dan kontrol perempuan

Tabel 2. Kesenjangan Gender untuk Pengambilan Keputusan dalam Kegiatan Penangkapan Ikan, 2019.

\begin{tabular}{lrrrrrrr}
\hline \multirow{2}{*}{ Kecamatan } & \multirow{2}{*}{$\mathbf{N}$} & \multicolumn{3}{c}{ Lama Melaut (\%) } & \multicolumn{3}{c}{ Jumlah Tenaga Kerja (\%) } \\
\cline { 3 - 8 } & & (a) & (b) & (c) & (a) & (b) & (c) \\
\hline Bunguran Selatan & 8 & 100,0 & 0,0 & 0,0 & 100,0 & 0,0 & 0,0 \\
Bunguran Timur & 19 & 100,0 & 0,0 & 0,0 & 100,0 & 0,0 & 0,0 \\
Bunguran Timur Laut & 15 & 53,3 & 0,0 & 46,7 & 46,7 & 0,0 & 53,3 \\
Bunguran Utara & 5 & 0,0 & 0,0 & 100,0 & 0,0 & 0,0 & 100,0 \\
Pulau Tiga & 5 & 33,3 & 0,0 & 66,7 & 66,7 & 0,0 & 33,3 \\
\hline
\end{tabular}

Keterangan:

$\mathrm{N}$ = jumlah responden; (a) dominasi laki-laki; (b) dominasi perempuan; (c) dominasi laki-laki dan perempuan.

Sumber: Data Primer Diolah, 2019 
Tabel 3. Kesenjangan Gender pada Pengambilan Keputusan Tempat Pendaratan, Alokasi Penjualan dan Sistem Penjualan, di Natuna 2019.

\begin{tabular}{|c|c|c|c|c|c|c|c|c|c|c|}
\hline \multirow[t]{2}{*}{ Kecamatan } & \multirow[t]{2}{*}{$\mathbf{N}$} & \multicolumn{3}{|c|}{$\begin{array}{c}\text { Penentuan Lokasi } \\
\text { Mendaratkan Ikan (\%) }\end{array}$} & \multicolumn{3}{|c|}{$\begin{array}{c}\text { Alokasi Penjualan Hasil } \\
\text { Tangkapan (\%) }\end{array}$} & \multicolumn{3}{|c|}{$\begin{array}{c}\text { Sistem Penjualan Hasil } \\
\text { Tangkapan (\%) }\end{array}$} \\
\hline & & (a) & (b) & (c) & (a) & (b) & (c) & (a) & (b) & (c) \\
\hline Bunguran Selatan & 8 & 100,0 & 0,0 & 0,0 & 100,0 & 0,0 & 0,0 & 0,0 & 12,5 & 87,5 \\
\hline Bunguran Timur & 19 & 84,2 & 0,0 & 15,8 & 84,2 & 0,0 & 15,8 & 94,7 & 0,0 & 5,3 \\
\hline Bunguran Timur Laut & 15 & 80,0 & 0,0 & 20,0 & 73,3 & 0,0 & 26,7 & 66,7 & 0,0 & 33,3 \\
\hline Bunguran Utara & 5 & 100,0 & 0,0 & 0,0 & 100,0 & 0,0 & 0,0 & 100,0 & 0,0 & 0,0 \\
\hline Pulau Tiga & 5 & 66,7 & 0,0 & 33,3 & 33,3 & 0,0 & 66,7 & 33,3 & 0,0 & 66,7 \\
\hline
\end{tabular}

Keterangan:

$\mathrm{N}=$ jumlah responden; (a) dominasi laki-laki; (b) dominasi perempuan; (c) dominasi laki-laki dan perempuan.

Sumber: Data Primer Diolah, 2019.

yang lemah dalam penentuan lokasi pendaratan ikan pada lima kecamatan di Natuna menunjukkan perempuan tidak diberi akses di dalam keputusan menentukan lokasi pendaratan ikan, tetapi dipengaruhi oleh toke ikan. Toke ikan Natuna telah memberi modal kegiatan penangkapan ikan sehingga penentuan lokasi dikendalikan oleh nelayan bersama toke. Beberapa nelayan yang tidak tergantung pada toke, keputusan mendaratkan ikan ditentukan dengan keputusan bersama, karena perempuan (istri nelayan) selanjutnya akan memasarkan hasil tangkapan itu ke pasar. Akses dan kontrol perempuan seperti itu hanya terjadi pada beberapa responden di Kecamatan Bunguran Timur, Bunguran Timur Laut, dan Kecamatan Pulau Tiga. Keputusan ini sangat rapuh dan dapat berubah jika responden tersebut menerima modal atau biaya melaut dari toke ikan Natuna. Perubahan ini dapat terjadi karena koperasi nelayan di Natuna masih belum berfungsi.

Fenomena kesenjangan gender tentang keputusan alokasi penjualan hasil tangkapan erat kaitannya dengan keputusan penentuan lokasi pendaratan ikan. Alokasi penjualan tersebut berkaitan dengan tujuan kerja sama yang dibangun toke ikan dari luar Natuna dan toke ikan Natuna dengan nelayan perikanan skala kecil. Kerja sama tersebut adalah untuk mendapatkan alokasi hasil tangkapan nelayan untuk dijual ke pasar ekspor (Singapura), sehingga akses dan kontrol perempuan terhadap keputusan alokasi penjualan hasil tangkapan sangat terbatas seperti di Kecamatan Bunguran Timur dan Kecamatan Bunguran Timur Laut. Di Kecamatan Pulau Tiga, akses keputusan kompromi laki-laki dan perempuan tentang alokasi penjualan cukup besar karena ikan yang dijual harus dikumpulkan di tempat responden sebelum diambil pedagang (toke) karena masalah transportasi.

Pada Kecamatan Bunguran Timur dan Bunguran Timur Laut, kesenjangan gender terjadi di dalam menentukan penjualan hasil tangkapan. Pada dua kecamatan tersebut, keputusan kompromi laki-laki dan perempuan hanya 5,3\% di Bunguran Timur dan 33,3\% di Bunguran Timur Laut. Keputusan penjualan hasil tangkapan didominasi oleh laki-laki di Bunguran Timur (94,7\%) dan Bunguran Timur Laut $(66,7 \%)$, karena kegiatan penangkapan ikan sebagian besar responden dibiayai oleh toke, dengan demikian hasil tangkapan harus dijual kepada toke tersebut. Dengan demikian, perempuan tidak mendapat akses untuk mempengaruhi keputusan tersebut. Di Kecamatan Bunguran Selatan, keputusan pembayaran hasil penangkapan ikan dan penggunaan pendapatan merupakan keputusan kompromi antara laki-laki dan perempuan. Keputusan tersebut menunjukkan istri nelayan diberi kesempatan dan wewenang didalam pengambilan keputusan (Tabel 4).

Sementara di Kecamatan Bunguran Utara, sistem pembayaran $100 \%$ merupakan keputusan yang didominasi oleh laki-laki, hal ini berkaitan erat dengan kebiasaan nelayan skala kecil yang menerima biaya operasi penangkapan ikan dari toke, sehingga nelayan punya kewajiban membayar pinjaman tersebut. Penggunaan pendapatan hasil penangkapan ikan setelah dikeluarkan pinjaman biaya penangkapan ikan merupakan keputusan kompromi laki-laki dan perempuan. Keputusan kompromi penggunaan pendapatan pada responden di Bunguran Selatan, Bunguran Utara, dan Pulau Tiga menujukkan istri nelayan perikanan skala diberi wewenang mengelola uang tersebut untuk keperluan ekonomi rumah tangga (Tabel 4). 
Tabel 4. Kesenjangan Gender pada Proses Pengambilan Keputusan Penggunaan Pendapatan dan Sistem Pembayaran.

\begin{tabular}{lcrrrrrr}
\hline \multirow{2}{*}{ Kecamatan } & \multirow{2}{*}{$\mathbf{N}$} & \multicolumn{4}{c}{ Penggunaan Pendapatan (\%) } & \multicolumn{3}{c}{ Sistem Pembayaran (\%) } \\
\cline { 3 - 8 } & & \multicolumn{1}{c}{ (a) } & (b) & (c) & (a) & (b) & (c) \\
\hline Bunguran Selatan & 8 & 0,0 & 0,0 & 100,0 & 0,0 & 0,0 & 100,0 \\
Bunguran Timur & 19 & 78,9 & 0,0 & 21,1 & 89,5 & 0,0 & 10,5 \\
Bunguran Timur Laut & 15 & 80,0 & 0,0 & 20,0 & 73,3 & 0,0 & 26,7 \\
Bunguran Utara & 5 & 0,0 & 0,0 & 100,0 & 100,0 & 0,0 & 0,0 \\
Pulau Tiga & 5 & 33,3 & 0,0 & 66,7 & 33,3 & 0,0 & 66,7 \\
\hline
\end{tabular}

Keterangan:

$\mathrm{N}$ = jumlah responden; (a) dominasi laki-laki; (b) dominasi perempuan; (c) dominasi laki-laki dan perempuan.

Sumber: Data Primer Diolah, 2019

Pada Kecamatan Bunguran Timur dan Bunguran Timur Laut, keputusan penggunaan pendapatan hasil penjualan ikan dan sistem pembayaran hasil penangkapan ikan merupakan keputusan yang didominasi laki-laki. Akses dan kontrol perempuan terhadap keputusan itu sangat terbatas, hal itu dapat dilihat dari keputusan kompromi laki-laki dan perempuan di Bunguran Timur $(21,1 \%)$ dan Bunguran Timur Laut $(20,0 \%)$ terkait penggunaan pendapatan; serta keputusan kompromi pada sistem pembayaran hasil penjualan pada kedua kecamatan masing-masing $10,5 \%$ dan $26,7 \%$ (Tabel 4). Hal ini menunjukkan peran toke sangat besar dan mempengaruhi penggunaan pendapatan hasil tangkapan dan sistem pembayaran.

\section{STRATEGI MENUJU KESETARAAN GENDER PADA PERIKANAN SKALA KECIL}

Kesenjangan gender karena dominasi peran laki-laki adalah hal yang umum pada perikanan skala kecil di Kabupaten Natuna. Dominasi laki-laki terhadap keputusan-keputusan yang diambil dalam memanfaatkan perikanan skala kecil di Kabupaten Natuna terjadi karena kebiasaan nelayan setempat. Tabel 5 menunjukkan strategi menuju kesetaraan gender (gender equality) sebagai implikasi kesenjangan gender yang terjadi pada perekonomian dan perikanan skala kecil di Natuna. Kesenjangan gender pada masyarakat perikanan di dalam pemanfaatan perikanan skala kecil disebabkan juga oleh terbatasnya daya serap pasar tenaga kerja terhadap perempuan. Padahal potensi perempuan berpartisipasi di dalam berbagai kegiatan ekonomi di Kabupaten Natuna dapat diandalkan. Sebagai contoh, partisipasi perempuan pada kegiatan menangkap ikan teri di pesisir pantai untuk olahan teri kering dan pede' yang sering dilakukan beberapa perempuan dari Desa Cemaga, Cemaga Selatan dan Cemaga Utara Kecamatan Bunguran Selatan. Hal ini menunjukkan perempuan dapat berpartisipasi pada program pembangunan perikanan skala kecil. Oleh sebab itu, program pembangunan perikanan skala

Tabel 5. Kesenjangan Gender dan Strategi Menuju Kesetaraan Gender pada Perikanan Skala Kecil di Natuna, 2019.

\begin{tabular}{lll}
\hline No. & \multicolumn{1}{c}{ Kesenjangan Gender } & \multicolumn{1}{c}{ Strategi Menuju Kesetaraan Gender } \\
\hline 1. & Kesenjangan pendapatan laki-laki dan perempuan & Pemerintah daerah harus merancang program \\
& pada perekonomian Natuna & untuk membuka lapangan kerja perempuan dengan \\
& & menstimulasi industri pengolahan skala rumah \\
& tangga menjadi skala kecil dan menengah, serta \\
& mendorong tumbuhnya industri pengolahan lain.
\end{tabular}

2. Kebiasaan mengambil keputusan di Tempat Pendaratan Ikan (tempat yang jarang diakses perempuan)

Melaksanakan kegiatan rutin untuk perempuan di TPI agar istri nelayan dapat beraktivitas pada lokasi tersebut.

3. Relasi nelayan dengan toke ikan Natuna untuk Melatih istri nelayan sebagai pengurus kapal mendapat biaya operasi penangkapan ikan, pada relasi penangkap ikan itu perempuan tidak diberi akses dan kontrol.

4. Relasi nelayan dengan toke ikan dari luar Natuna, pada Melatih istri nelayan sebagai pengurus kapal relasi ini perempuan hanya diberi akses dan wewenang penangkap ikan terbatas 
kecil harus memperhatikan kebutuhan perempuan, seperti menyediakan bantuan alat tangkap teri sesuai dengan spesifikasi yang dapat digunakan perempuan.

Di Kabupaten Natuna, industri pengolahan yang berkembang umumnya industri rumah tangga, seperti usaha pengasapan ikan, usaha pembuatan pede' (penyedap dari ikan teri), usaha pengolahan ikan teri serta usaha pembuatan amplang. Namun industri pengolahan ini kontribusinya sangat kecil dalam struktur perekonomian Kabupaten Natuna (BPS Kabupaten Natuna, 2020). Pemerintah daerah harus merancang program yang mendorong usaha rumah tangga tersebut menjadi industri kecil dan menengah pengolahan hasil perikanan, atau memfasilitasi industri pengolahan baru (seperti pemanfaatan buah kelapa dan produk turunannya) yang menyerap tenaga kerja perempuan antara 5 sampai 10 orang. Industri yang terakhir ini dapat menjadi penyangga kehidupan ekonomi rumah tangga nelayan.

Kesenjangan gender ditentukan oleh akses terhadap tempat pendaratan ikan di Natuna. Lokasi tersebut merupakan tempat berkumpul nelayan (laki-laki) serta sering digunakan sebagai tempat mengambil berbagai keputusan kegiatan penangkapan ikan. Keputusan yang dihasilkan adalah keputusan yang bias gender, karena tidak melibatkan perempuan, karena perempuan tidak pernah berada pada tempat pendaratan ikan tersebut. Tempat pendaratan ikan merupakan lokasi strategis untuk membangun komunikasi antar nelayan, sehingga tempat tersebut harus dijadikan sebagai basis kegiatan ekonomi istri nelayan. Program-program pemberdayaan ekonomi istri nelayan (seperti pengasapan ikan, pengolahan ikan atau fillet ikan) untuk pengembangan perekonomian Natuna harus terkoneksi atau beraktivitas di tempat pendaratan ikan. Sehingga, keputusan jenis ikan yang ditangkap dan didaratkan nelayan di tempat pendaratan ikan akan sesuai dapat memenuhi permintaan usaha yang dikembangkan istri nelayan.

Relasi nelayan dengan pedagang ikan Natuna serta pedagang ikan dari luar Natuna terhadap keputusan biaya penangkapan ikan menghasilkan keputusan yang bias gender, karena akses perempuan pada relasi tersebut relatif tidak ada dengan toke ikan Natuna dan sangat terbatas dengan toke ikan dari luar Natuna. Akses perempuan dengan toke ikan tersebut dapat dirintis dengan mengikutsertakan istri nelayan menjadi pengurus untuk mengelola kapal penangkapan ikan. Keikutsertaan istri nelayan mengurus kapal ikan bermanfaat untuk mengatur cash flow usaha penangkapan ikan (yang terkait dengan toke ikan), menjadi sarana untuk melakukan transformasi usaha perikanan skala kecil di Natuna one day fishing menjadi usaha perikanan komersial yang menangkap ikan lebih dari satu hari per trip. Keikutsertaan perempuan mengurus armada penangkapan ikan (terutama perbekalan melaut dan keuangan) harus didorong agar armada perikanan tangkap menjadi armada yang besar dan mempunyai pengaruh pada perekonomian Natuna. Peran yang demikian telah ditunjukkan oleh perempuan yang menjadi pengurus armada perikanan di Pelabuhan Perikanan Nusantara Bitung. Peran perempuan dalam urusan domestik diatur dengan memanfaatkan pihak lain (warung makan serta menggunakan tenaga kerja bayaran untuk mengurus rumah).

\section{PENUTUP}

Relasi laki-laki dan perempuan menjadi bagian penting dalam membangun perekonomian dan pengembangan perikanan skala kecil di Kabupaten Natuna. Kontribusi perempuan pada berbagai aktivitas di dalam kegiatan persiapan penangkapan ikan, penangkapan ikan, dan paska penangkapan ikan masih terbatas. Di Kabupaten Natuna terdapat lapangan usaha yang kontribusinya kecil dalam perekonomian, namun, mampu menampung tenaga kerja perempuan dalam jumlah besar (Lapangan Usaha Industri Pengolahan). Lapangan usaha ini harus didorong dengan program pembangunan agar skala usahanya berubah tidak lagi skala usaha rumah tangga. Pada sisi lain terdapat lapangan usaha yang kontribusinya besar (Pertambangan dan Penggalian), tetapi penyerapan tenaga kerjanya terbatas karena skill yang dipersyaratkan untuk dapat bekerja pada lapangan usaha tersebut. Oleh sebab itu, skill tenaga kerja laki-laki dan perempuan untuk lapangan usaha seperti ini harus disiapkan oleh Pemerintah Daerah Kabupaten Natuna.

Pada relasi gender perikanan skala kecil di Kabupaten Natuna, peran toke (pedagang) Natuna dan dari luar Natuna sangat berpengaruh. Oleh sebab itu, pemerintah daerah perlu melibatkan toke agar pembangunan ekonomi masyarakat perikanan di Kabupaten Natuna dapat berkembang. Toke ikan tersebut perlu dijadikan mitra kerja sama pemerintah di dalam melakukan program 
pengarusutamaan gender untuk mewujudkan berfungsinya SKPT dan mengembangkan tempat pendaratan ikan. Toke ikan tersebut perlu dijadikan mitra untuk menumbuhkan bisnis pengolahan ikan pada tempat pendaratan ikan sehingga kehadiran perempuan pada tempat tersebut dapat terwujud.

Program untuk mewujudkan kesetaraan gender menjadi momentum penting yang dapat meningkatkan partisipasi perempuan dalam pembangunan ekonomi di Natuna. Partisipasi tersebut dapat dirancang Pemerintah Daerah Kabupaten Natuna melalui program yang memberikan ruang kepada perempuan dengan melakukan trasformasi industri skala rumah tangga yang menggunakan tenaga kerja dalam keluarga menjadi industri kecil dan menengah yang menampung 5 sampai 10 tenaga kerja perempuan dengan upah yang adil.

Membangun akses dan mobilisasi kegiatan pemberdayaan ekonomi istri nelayan ke tempat pendaratan ikan, sehingga kegiatan tersebut dapat menghasilkan keputusan yang adil gender. Oleh sebab itu, Pemerintah Daerah Kabupaten Natuna harus merancang program peningkatan kapasitas perempuan (istri nelayan), yang terkait dengan manajemen usaha perikanan sehingga perempuan dapat menjadi bagian dari pengelolaan aktivitas kapal penangkapan ikan, dan melalui mereka sistim penangkapan ikan di Natuna dapat dikembangkan menjadi perikanan skala komersial.

\section{UCAPAN TERIMA KASIH}

Terima kasih kepada tim peneliti "resiliensi masyarakat pesisir terhadap dampak perubahan iklim di Laut Cina Selatan" tahun 2019 serta Penyuluh Perikanan Tenaga Bantu Kabupaten Natuna yang telah bersedia mengumpulkan data sekunder dan primer terkait dengan gender pada perikanan skala kecil. Terima kasih juga kepada PIt. Kepala BBRSEKP yang telah membiayai kegiatan ini melalui anggara Analisis Kebijakan BBRSEKP tahun 2019. Terima kasih kepada tim redaksi dan mitra bestari yang telah berperan dalam review substansi dan saran perbaikan untuk makalah ini.

\section{PERNYATAAN KONTRIBUSI PENULIS}

Kontributor utama tulisan ini adalah: Armen Zulham. Peran kontributor utama merancang kuesioner data terpilah gender, menentukan substansi pertanyaan kuesioner gender, merancang tampilan data olahan dalam tulisan, serta melakukan analisis maupun menuliskan substansi tulisan. Kontributor anggota terdiri dari: Rani Hafsaridewi, Hikmah, Permana Ari Soejarwo, dan Bayu Vita Indah Yanti. Kontributor anggota bersama kontributor utama melakukan wawancara responden, melakukan editing, dan pengolahan data. Pernyataan kontributribusi penulis telah dilampirkan bersama dengan naskah ini.

\section{DAFTAR PUSTAKA}

Anonim. (2015). Humanity Divided: Confronting inequality in developing countries. Gender inequality (Chapter 5) p: 161-193. https://www. undp.org/content/dam /undp/library /Poverty\% 20Reduction/Inclusive \%20development/ Humanity\% 20Divided/HumanityDivided_Ch5_ low.pdf.

Barclay K., Leduc B., Mangubhai S., Vunisea A., Namakin B., Teimarane M. \& Leweniqila L. (2019). Module 1: Introduction. In: Barclay K., Leduc B., Mangubhai S. and Donato-Hunt C. (eds.). Pacific handbook for gender equity and social inclusion in coastal fisheries and aquaculture. Pacific Community (SPC), Noumea, New Caledonia. 20 p.

Bennett, E. (2005). Gender, fisheries and development. Marine Policy, 29: 451-459.

[BPS] Badan Pusat Statistik Kabupaten Natuna. (2020). Kabupaten Natuna Dalam Angka 2019. pp 374.

[DKP] Dinas Kelautan dan Perikanan Kabupaten Natuna. (2020). Buku Saku Perikanan Natuna 2019. pp 45.

Dunham, S.A. (2008). Revolusi Hijau dan Masalah Kesenjangan Sosial dalam Pendekar Pendekar Besi Nusantara. Penerbit Mizan. pp: 70-75.

Damsar, \& Indrayani. (2009). Pengantar Sosiologi ekonomi. Edisi kedua. Penerbit Kencana Prenadamedia Group. pp. 318.

Fitriana, R \& M. Kurufat. (2020). Changing land use patterns threaten the livelihood of female crab collectors in Merauke, Papua, Indonesia. Yemaya, ICFS's Newsetter on Gender and Fisheries. No.61. Augut. 2020. pp: 6-8.

Groenmeyer, S. (2015). The long road to freedom. Yemaya, ICFS's Newsetter on Gender and Fisheries. No.50. Dec. 2015. pp: 8-10.

Harper, S. (2016). Counting on Women. Yemaya, ICFS's Newsetter on Gender and Fisheries. No.51. April 2016. pp: 2-4.

Hakiki, G., Supriyanto, S., Ulfah, A., Prastiwi, D., Larasati, W., Khoer, M. I. (2019). Profil Perempuan Indonesia 2019. Kerja sama Kementerian Pemberdayaan Perempuan dan Perlindungan Anak serta Badan Pusat Statistik. 
Hikmah, Nurlaili, \& Soejarwo, P. A. (2020). Analisis gender pada rumah tangga nelayan di Desa Cituis Kabupaten Tangerang, dalam Zulham, Hikmah, Shafitri, \& Yuliaty (eds). Pemberdayaan Perempuan dan Kematangan Gender Kelompok Usaha Perikanan. IPB Press. pp: 186.

ILO. (2016). Empowering Women in Rural Economy. Decent Work in the Rural Economy. Policy Guidance Notes. ILO Office. Geneve. p.16.

Kurniawan, T., Triyanti, R., \& Nurlaili. (2020). Kinerja program pengarusutamaam gender di Sektor Kelautan dan Perikanan, dalam Zulham, Hikmah, Shafitri, \& Yuliaty (eds). Pemberdayaan Perempuan dan Kematangan Gender Kelompok Usaha Perikanan. IPB Press. pp: 186.

Levy, C. (1996). 'The Process of Institutionalising Gender in Policy and Planning: The "Web" of Institutionalisation', Working Paper No. 74, Development Planning Unit, University College London.

Lopes, J. L., Duarte, A., \& Tilley, A. (2020). Strong Women, Strong Nation. Samudera No.83. September 2020: 29 - 32.

Lepeniotia, K., Bousdekisa, A., Apostolou, D., \& Mentzas, G. (2020). Prescriptive analytics: Literature review and research challenges. International Journal of Information Management 50 (2020) 57-70.

Moser, C. (1993). Gender Planning and Development 'Theory, Practice and Training'. Routledge, London.

Paul, P., \& Meena, B. S. (2016). A study on access to and control over resources: gender perspective. International Journal of Science, Environment and Technology, Vol. 5, No 5, 2016, 2982 - 2988.

Ponthieux, S., \& Dominique, M. (2015). Gender Inequality. Handbook of Income Distribution. Chapter 12. Vol.2:981-1146.

Rahmawati, F., \& Abdulkadir-Sunito, M. (2013). The Influencing Factors of Access and Control Men and Women in Community Forest Resources Management. Sodality: Jurnal Sosiologi Pedesaan. Vol (01) 03: 206-221

Rahayu, W. K. (2016). Analsis pengarusutamaan gender dalam kebijakan publik (studi kasus di BP3AKB Provinsi Jawa Tengah). Jurnal Analisis dan Pelayanan Publik. Vol (2)1.

Shafitri, N., Triyanti, R., \& Zulham, A. (2020). Pengarusutamaan gender pada komunitas perikanan skala kecil, dalam Zulham, Hikmah, Shafitri, \& Yuliaty (eds). Pemberdayaan Perempuan dan Kematangan Gender Kelompok Usaha Perikanan. IPB Press. pp: 186
Sofiani, T. (2009). Membuka ruang partisipasi perempuan dalam pembangunan. Muwazah 1(1): 63-71.

Triyanti, R., Shafitri, N., \& Kurniawan, T. (2020). Gender pada kelompok rumah tangga pengolah hasil perikanan, dalam Zulham, Hikmah, Shafitri dan Yuliaty (eds). Pemberdayaan Perempuan dan Kematangan Gender Kelompok Usaha Perikanan. IPB Press. pp: 186.

Villamor, G. B., Meine, V. N., Utkur, D., Ma Elena, C., \& Delia, C. (2014). Gender differences in land-use decisions: shaping multifunctional landscapes? Current Opinion in Environmental Sustainability: 2014, 6:128-133. http://dx.doi.org/10.1016/j. cosust. 2013.11.015

Winarno, B. (2003). Komparasi organisasi pedesaan dalam pembangunan: Indonesia vis-à-vis Taiwan, Thailand dan Filipina. Media Pressindo. pp: 264.

Wardono, B., Muhartono, R., Apriliany, T., Hikmah, \& Zulham, A. (2020). Traditional Fisheries Supply Chain Management in The Border Area: The Natuna Islands, Indonesia. Proceeding The $3^{\text {rd }}$ International Symposium on Marine and Fisheries Research (3 ${ }^{\text {rd }}$ ISMFR). Volume 147 (2020). DOI: https://doi.org/10.1051/ e3sconf/202014702009

World Economic Forum. (2014). Gender, gender concept and definition. Modul 1. Manual for Trainers: Gender Equality and Gender Mainstraiming. 14 pages. Available at: http://reports.weforu.org/_ static/global_gender_gap-2014/MNG.pdf.

Zulham, A. (2020). Prolog: peran perempuan dan gender dalam pembangunan perikanan. Dalam Zulham, Hikmah, Shafitri dan Yuliaty (eds). Pemberdayaan Perempuan dan Kematangan Gender Kelompok Usaha Perikanan. IPB Press. pp: 186.

Zulham,A., Subaryono, \& Regy, F.A. (2017). Rekomendasi Pengembangan Perikanan Tangkap Di Natuna Dan Sekitarnya. Penerbit. PT RajaGrafindo Persada, Depok. pp. 66 